\title{
Changes in Plasma Protein Profiles in Serum and in Liver DNA Synthesis of Rats Following Administration of $\alpha$-Amanitin, Phalloidin and/or Carbon Tetrachloride
}

\author{
By M. Goldberg, F. M. Fouad and G. Ruhenstroth-Bauer \\ Max-Planck-Institut für Biochemie, Arbeitsgruppe Experimentelle Medizin, Martinsried, FRG
}

(Received April 19/August 26, 1982)

Summary: The aim of the present study is to investigate the capacity of damaged rat liver cells to respond to a second inflammation by a change in plasma protein profile, while the first inflammatory process is in progress. Quantitation of these effects would be useful, especially in situations, where patients are suffering from complications due to emergence of a new pathological factor. We therefore studied the effect of phalloidin on rat livers already made necrotic by oral intubation of $\mathrm{CCl}_{4}$. Our data showed that a decrease in acute-phase response does not necessarily always imply healing, but may also be indicative of a second pathological complication.

Veränderungen des Plasmaprotein-Profils im Serum und der DNA-Synthese in der Rattenleber nach Verabreichung von $\alpha$-Amanitin, Phalloidin und/oder Tetrachlorkohlenstoff

Zusammenfassung: Das Ziel dieser Arbeit ist die Untersuchung der Fähigkeit geschädigter Rattenleberzellen, auf eine zweite, weitere Entzündung mit einer Veränderung des Plasmaprotein-Profils zu reagieren, während noch der erste entzündliche Prozeß in Gang ist. Das Ërfassen dieser Effekte wäre insbesondere in Situationen nützlich, bei denen Patienten eine zweite pathologische Einwirkung erleiden. Deshalb untersuchten wir die Folge einer Phalloidin-Vergiftung in einer Rattenleber, die durch vorhergehende Intubation mit $\mathrm{CCl}_{4}$ nekrotisiert worden war. Die Ergebnisse zeigen, daß eine Verminderung der „Akute-Phase-Reaktion“ nicht immer Heilung bedeuten muß, sondern ebenso durch eine weitere krankhafte Komplikation hervorgerufen werden kann.

\section{Introduction}

In several reports we have described the changes in plasma protein levels in cases of Yoshida sarcoma or Zajdela Ascites (1) and during the inflammatory response in rats, induced by carageenan $(2,3,4)$. We have also shown that addition of an inflammatory mediator (leukocytic endogenous mediator) to liver cells initiates an acute-phase response in vitro (5). From our results and those of other investigators $(1,4)$ it appears that, at least in the first few days the changes in acute-phase response are proportional to the severity of the inflammation $(1,4)$.
Therefore we studied the ability of injured rat liver cells to respond to a second injury while the first process is in progress. Quantitation of the change in plasma protein profile would be advantageous especially in situations where patients are suffering from complications due to the emergence of a new pathological factor, e.g., gastric ulceration following long surgery.

We have used two rate models, namely:

a) $\alpha$-Amanitin poisoning and

b) Phalloidin poisoning of necrotic livers induced by oral intubation of $\mathrm{CCl}_{4}$. 


\section{Experimental}

\section{Animals}

Specific pathogen-free Wistar rats (Institut für Strahlen- und Umweltforschung Neuherberg/München) weighing $100-200 \mathrm{~g}$, were used. Food (Altromin 1324) and water were given ad libitum.

\section{Chemicals and reagents}

Phalloidin and $\alpha$-amanitin were kindly donated by Dr. H. Faulstich, Heidelberg (FRG). $\mathrm{CCl}_{4}$ was purchased from Merck/Darmstadt (FRG) and $\left[6-{ }^{3} \mathrm{H}\right]$ thymidine was from Amersham-Buchler/ Braunschweig (FRG). Polyvalent rabbit antiserum against rat serum proteins was purchased from Boehringer/Mannheim (FRG).

\section{Methods}

$\mathrm{CCl}_{4}$ was administered to rats by stomach tube $(2 \mathrm{ml} / \mathrm{kg}$ body weight). The Amanita toxins, phalloidin and $\alpha$-amanitin, were given by intraperitoneal injection $(1.2 \mathrm{mg} / \mathrm{kg}$ body weight in $0.5 \mathrm{ml}$ saline). At different time intervals, animals were sacrified between 9.00 and $10.00 \mathrm{a}$. m. Blood was withdrawn to separate serum for immunologicäl tests and livers were removed for determination of the DNA synthesis in hepatocytes.

\section{Two-dimensional immunoelectrophoresis}

$6 \mu \mathrm{l}$ of blood serum were applied to agarose gel (Behringwerke Marburg/Lahn, FRG; $10 \mathrm{~g} /$ in barbital buffer $\mathrm{pH}=8.6$ ) and separation of plasma proteins was carried out according to the modified technique developed in our laboratories (5). Polyvalent rabbit antiserum against rat serum proteins was used. Following a defined enlargement by optical projection, quantitation of the peak area of each precipitated protein was determined planimetrically.

\section{DNA synthesis}

DNA synthesis was determined by $\left[{ }^{3} \mathrm{H}\right]$ thymidine incorporation $\left(925 \cdot 10^{4} \mathrm{~Bq} / \mathrm{kg}\right.$ body weight, $\left.1 \mathrm{~h}\right)$ into the DNA fraction of isolated liver nuclei as described previously (6).

The following experiments with single doses were performed:

a) $\mathrm{CCl}_{4}$, phalloidin and $\alpha$-amanitin administered separately,

b) $\mathrm{CCl}_{4}$ and phalloidin administered at the same time,

c) phalloidin injected i.p. $24 \mathrm{~h}$ after administration of $\mathrm{CCl}_{4}$, and

d) $\mathrm{CCl}_{4}$ intubated $24 \mathrm{~h}$ after phalloidin administration.

\section{Results and Discussion}

\section{Poisoning with phalloidin or $\alpha$-amanitin}

Due to their different interaction with different constituents of the liver cell, poisoning of rat liver cells with phalloidin or $\alpha$-amanitin resulted in different profiles of DNA and plasma protein synthesis (fig. 1, tab. 1). In phalloidin poisoned rats, liver nuclei showed maximum DNA synthesis 27 hours after poisoning, whereas $\alpha$-amanitin depressed DNA synthesis below control levels (fig. 1). This is in agreement with the data from the literature. In phalloidin poisoned rats, increased DNA synthesis of rat liver

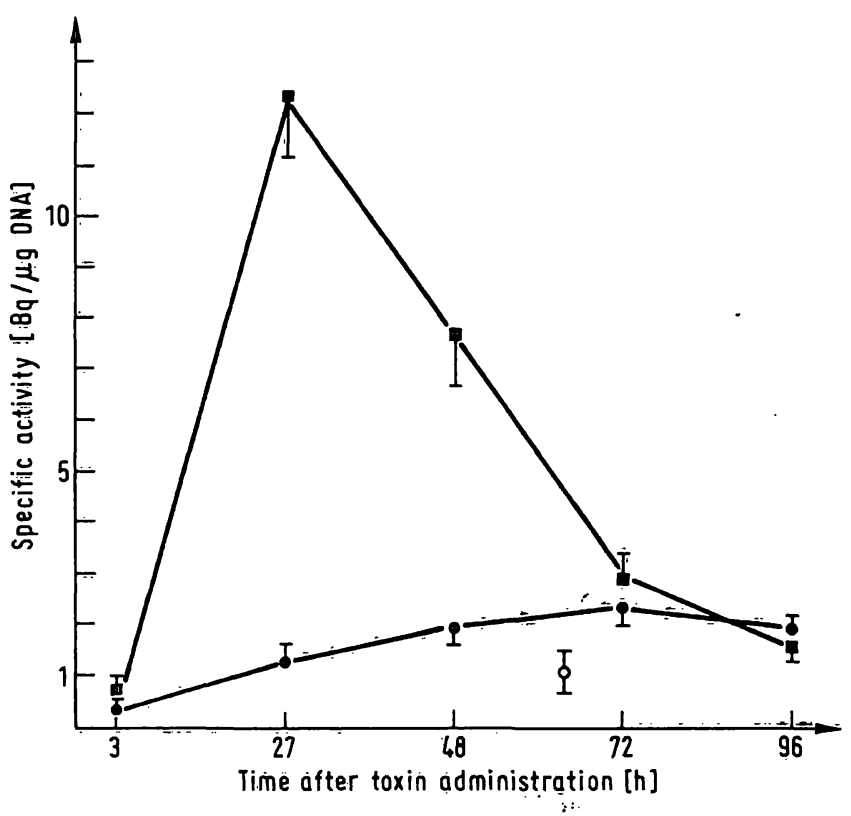

Fig. 1. $[3 \mathrm{H}]$ thymidine incorporation into DNA of rat liver cells after administration of

-

- $\alpha$-amanitin

-O- control

Tab. 1. Relative concentration of plasma proteins of rats poisoned with $\alpha$-amanitin and phalloidin $(1.2 \mathrm{mg} / \mathrm{kg} \mathrm{b}$. $\mathrm{w}$.). Values are the average of three experiments. Uncertainty in each value is \pm 0.05 .

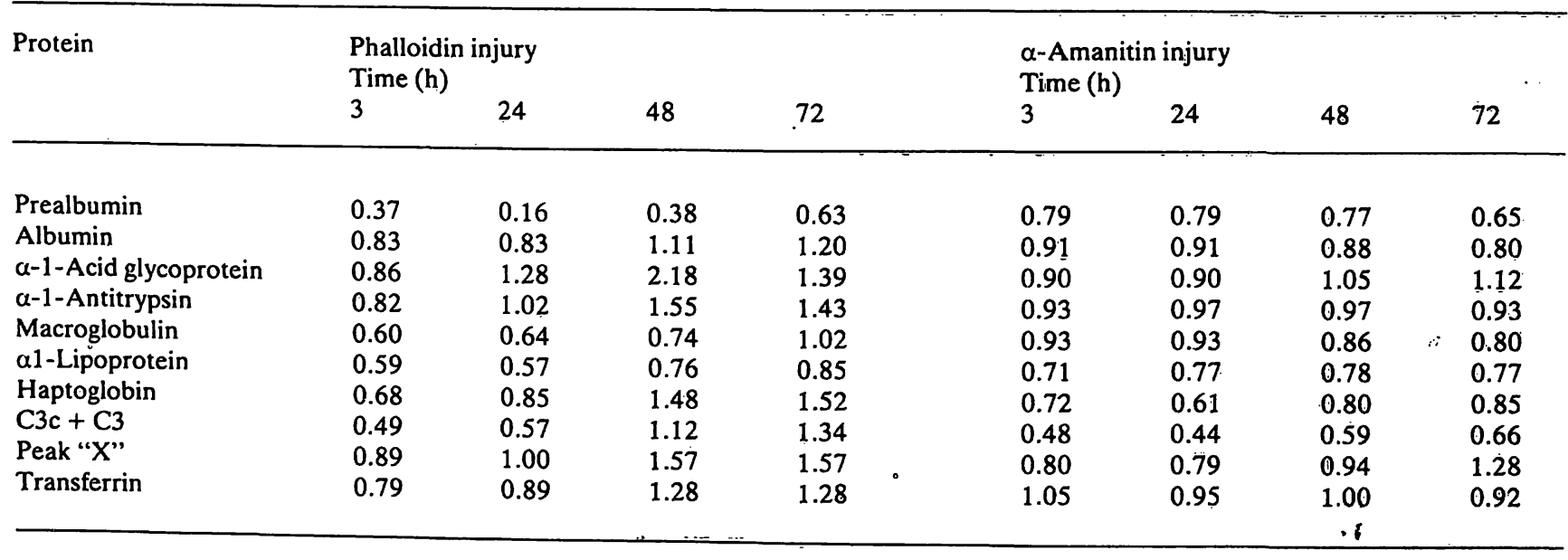


nuclei may be explained as a reaction to phalloidin binding to membrane actin (7), which leads to various disorders of the liver cell function (8) as a result of the labilization of membrane structure (9). Phalloidin may also be responsible for the disruption of the normal membrane ribosome mRNA unit. This disaggregation could be responsible for the sharp drop in plasma protein synthesis during the first day (tab. 1). However, levels of the identified plasma proteins increased during the 2 nd and 3 rd day of the experiment (tab. 1), which is expected in the light of increased DNA repair. On the other hand, inhibition of DNA-polymerase B of rat liver nuclei by $\alpha$-amanitin may result in a depressed DNA synthesis. This is further supported by our finding that $\alpha$-amanitin inhibited the effect of the liver cell proliferation factor hepatopoietin, when added to culture medium of healthy rat liver cells (10).

In contrast with phalloidin poisoning, the first three days of $\alpha$-amanitin poisoning showed a moderate decrease in the concentrations of plasma proteins, with the exception of haptoglobin and the $\mathrm{C} 3 \mathrm{c}+\mathrm{C} 3$ system. Most likely, the remaining mRNAs in the liver cells after poisoning with $\alpha$-amanitin are responsible for this observed mild decrease in plasma protein synthesis. The above data suggest that liver DNA and plasma protein biosynthesis can be influenced independently.

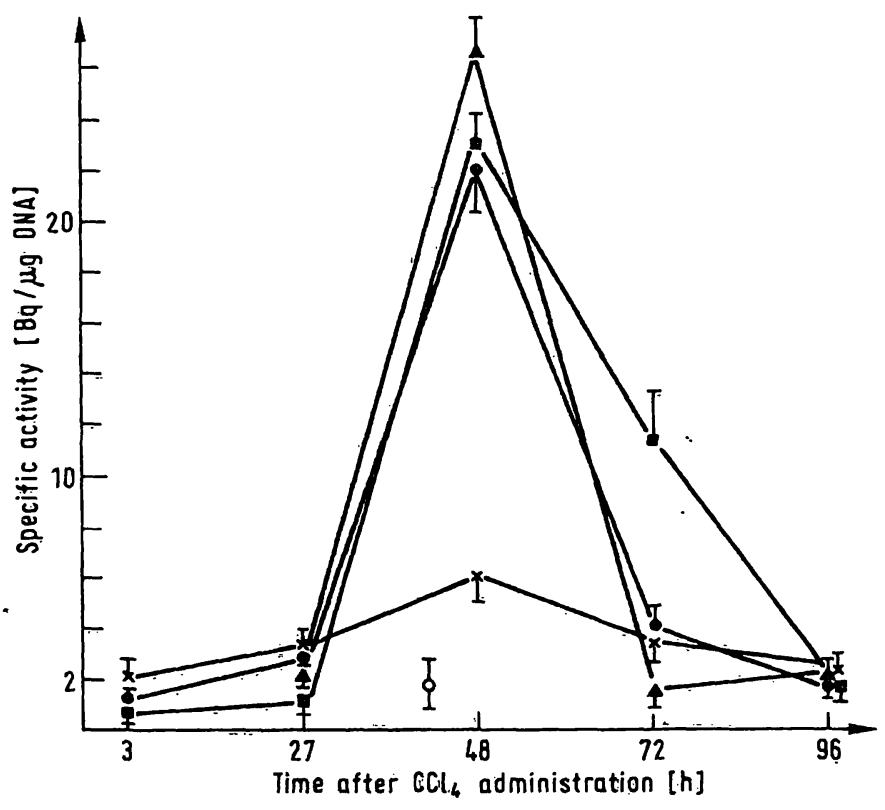

Fig. 2. $\left[{ }^{3} \mathrm{H}\right]$ thymidine incorporation into DNA of rat liver cells after administration of

$$
\begin{aligned}
& -1-\mathrm{CCl}_{4} \\
& -\mathrm{CCl} \text { and phalloidin at the same time } \\
& -\mathrm{CCl}_{4} \text { and phalloidin (24 h later) } \\
& -\mathrm{-}-\mathrm{CCl}_{4} \text { and phalloidin (24 h before) } \\
& -\mathrm{Control}
\end{aligned}
$$

\section{Poisoning with $\mathrm{CCl}_{4}$}

Intubation of $\mathrm{CCl}_{4}(2 \mathrm{ml} / \mathrm{kg}$ body weight $)$ into healthy rat stomachs led to increased DNA synthesis in liver cell nuclei. This effect is associated with liver cell necrosis (11). Maximum [ $\left.{ }^{3} \mathrm{H}\right]$ thymidine incorporation took place on the 2 nd day (fig. 2). We also observed a typical acute-phase reaction due to $\mathrm{CCl}_{4}$ induced liver cell necrosis which is similar to the reaction of the remaining liver lobes in partially hepatectomized rats (12). However, the magnitude and the duration of the acute-phase reaction in the two cases were different. Whereas maximum acutephase reaction in partially hepatectomized rats occurred during the second week and the maximum of the DNA synthesis 18 hours post surgery, in $\mathrm{CCl}_{4}$ induced liver regeneration the maximal acute-phase reaction coincided with the maximum DNA synthesis, i.e., 48 hours after intubation of $\mathrm{CCl}_{4}$ (fig. 2 and 3).
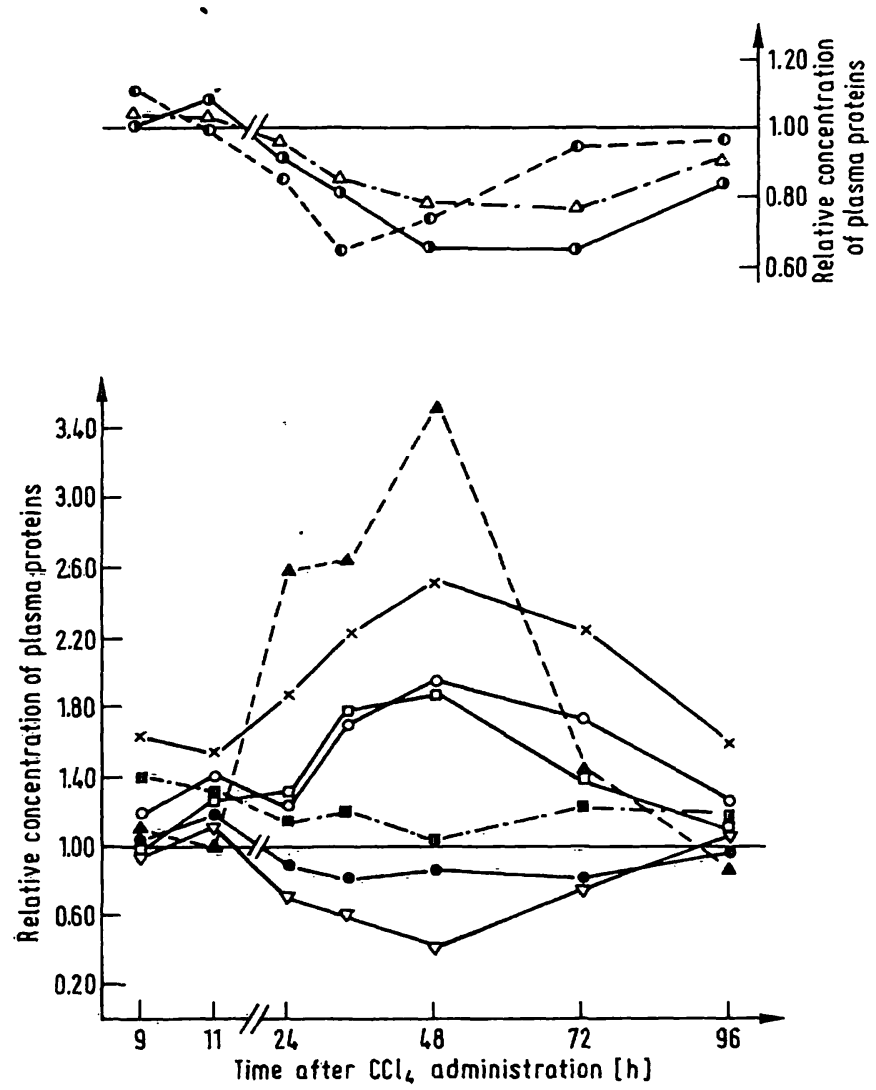

Fig. 3. Relative concentration of plasma proteins of $\mathrm{CCl}_{4}$ poisoned rats, mean standard deviation in brackets.

Left scale - - - albumin (0.02)

$-x-\alpha$-1-acid glycoprotein (0.22)

-O- $\alpha$-1-antitrypsin (0.02)

-

-A- haptoglobin $(0.14)$

一 - transferrin (0.03)

- $\nabla$ - prealbumin $(0.06)$

Right scale $-0-\mathrm{C}_{3} \mathrm{C}+\mathrm{C}_{3}(0.04)$

-1) macroglobulin $(0.02)$

$-\Delta-\alpha$-lipoprotein $(0.03)$ 


\section{Protection against phalloidin poisoning}

The decreased effect of phalloidin was very obvious in $\mathrm{CCl}_{4}$-induced regenerating liver when phalloidin was injected i.p. 24 hours after intubation of $\mathrm{CCl}_{4}$ (fig. 2 and tab.2A). For example, the levels of the main acute-phase reactants, i.e., $\alpha$-1-acid glycoprotein, haptoglobin and peak " $X$ ", released by the regenerative rat liver poisoned with phalloidin after $\mathrm{CCl}_{4}$ intubation, were higher on the 3rd and 4th days, compared with amounts released due to poisoning with phalloidin or $\mathrm{CCl}_{4}$ alone (fig. 3 and tab. 2A). This suggests: the rough endoplasmic reticulum-bound polyribosomes of $\mathrm{CCl}_{4}$-treated liver cells are active in translating mRNAs of the above acute phase reactants. Thereby they counter the effect of phalloidin poisoning compared with liver cells of rats poisoned with $\mathrm{CCl}_{4}$ or phalloidin alone. When phalloidin and $\mathrm{CCl}_{4}$ were applied simultaneously, this phenomenon was not observed but rather a de- pressed acute-phase reaction was detected. This indicates the failure of rough endoplâsmic reticulumbound polyribosomes of healthy rat liver cells to counter the damaging effects of both chemicals, applied simultaneously. However, it is surprising that $\left[{ }^{3} \mathrm{H}\right]$ thymidine incorporation was : not affected (fig. 2).

These results again support the hypothesis that $\mathrm{DNA}$ and protein biosynthesis can be influenced independently. That the latter deduction may have some merit is supported by the observation that

a) intubation of $\mathrm{CCl}_{4}$ into stomachs of rats injected 24 hours earlier with phalloidin resulted in a $72 \%$ decrease in $\left[{ }^{3} \mathrm{H}\right]$ thymidine incorporation in the 48th hour, and

b) an apparent increase in acute-phase reaction (tab. 2), compared with corresponding values, is obtained when phalloidin and $\mathrm{CCl}_{4}$ were administered simultaneously (tab. 2 and fig. 2).

Tab. 2. Relative concentration of plasma protein of rats poisoned with phalloidin and $\mathrm{CCl}_{4}$. Values are the average of three experiments. Uncertainty in each value is \pm 0.05 .

a) Phalloidin applied $24 \mathrm{~h}$ after intubation of $\mathrm{CCl}_{4}$

b) $\mathrm{CCl}_{4}$ intubated $24 \mathrm{~h}$ after i.p. injection of phalloidin, and

c) $\mathrm{CCl}_{4}$ and phalloidin administered simultaneously.

\begin{tabular}{|c|c|c|c|c|c|c|c|c|c|c|c|c|c|c|}
\hline \multirow[t]{2}{*}{ Protein } & \multicolumn{4}{|c|}{$\begin{array}{l}\text { A } \\
\text { Time (h) }\end{array}$} & \multicolumn{5}{|c|}{$\begin{array}{l}\text { B } \\
\text { Time (h) }\end{array}$} & \multicolumn{5}{|c|}{$\begin{array}{l}\text { C } \\
\text { Time (h) }\end{array}$} \\
\hline & 27 & 48 & 72 & 96 & 3 & 27 & 48 & $\mathbf{7 2}$ & 96 & 3 & 27 & -48 & 72 & 96 \\
\hline Prealbumin & * & * & $*$ & 0.21 & 0.51 & 0.31 & 0.42 & 0.37 & 0.58 & 0.52 & 0.53 & 0.22 & 0.22 & 0.58 \\
\hline Albumin & 0.58 & 0.79 & 0.93 & 1.00 & 0.81 & 0.84 & 0.86 & 0.86 & 1.12 & 0.73 & 0.87 & 0.73 & 0.88 & 0.84 \\
\hline$\alpha-1$-Acid glycoprotein & 1.95 & 2.48 & 2.52 & 1.82 & 1.44 & 1.82 & 1.71 & 1.55 & 1.11 & 0.88 & 1.26 & 1.32 & 1.31 & 1.41 \\
\hline$\alpha$-1-Antitrypsin & 0.67 & 0.81 & 0.92 & 0.89 & 1.36 & 1.87 & 1.66 & 1.45 & 1.48 & 0.80 & 0.94 & 1.69 & 1.76 & 1.63 \\
\hline Macroglobulin & 0.60 & 0.57 & 0.66 & 0.75 & 0.69 & 0.74 & 0.90 & 0.89 & 1.12 & 0.80 & 0.67 & 0.53 & 0.50 & 0.71 \\
\hline$\alpha$-1-Lipoprotein & 0.44 & 0.73 & 0.78 & 0.77 & 0.46 & 0.72 & 0.74 & 0.73 & 0.77 & 0.75 & 0.41 & 0.67 & 0.82 & 0.97 . \\
\hline Haptoglobin & 2.81 & 3.28 & 1.96 & 1.81 & 1.15 & 1.40 & 1.60 & 1.50 & 1.71 & 0.81 & 0.61 & 1.54 & 1.80 & 2.03 \\
\hline$C 3 c+C 3$ & 0.61 & 0.84 & 0.93 & 1.12 & 0.57 & 0.62 & 0.54 & 0.40 & 0.47 & 0.70 & 0.06 & 0.26 & 0.46 & 0.74 \\
\hline Peak "X" & 1.59 & 1.80 & 1.61 & 1.38 & 1.30 & 1.43 & 1.29 & 1.32 & 1.12 & 0.76 & 0.67 & 0.94 & 0.75 & 1.00 \\
\hline Transferrin & 1.02 & 1.06 & 1.39 & 1.36 & 1.12 & 1.26 & 1.08 & 0.99 & 1.33 & 0.83 & 0.79 & 0.89 & 0.98 & 1.17 \\
\hline
\end{tabular}

* Peak was visually not apparent

\section{References}

1. Scherer, R. \& Ruhenstroth-Bauer, G. (1978) Blut 36, $327-330$.

2. Scherer, R., Abd-El-Fattah, M. \& Ruhenstroth-Bauer, G. (1977) Perspectives in Inflammation, pp. 437-444, MTP Press, Lancester.

3. Abd-El-Fattah, M., Scherer, R. \& Ruhenstroth-Bauer, G. (1976) J. Mol. Med. 1, 211-221.

4. Abd-El-Fattah, M., Scherer, R., Fouad, F.M. \& Ruhenstroth-Bauer, G. (1981) Cancer Res. 41, 2498-2555.

5. Fouad, F. M., Scherer, R., Abd-El-Fattah, M. \& Ruhenstroth-Bauer, G. (1980) Eur. J. Cell Biol. 21, 175-179.

6. Goldberg, M., Strecker, W., Feeney, D. \& Ruhenstroth-Bauer, 'G. (1980) Horm. Metab. Res. 12, 94-96.
7. Govindan. V. M., Faulstich, H., Wieland, Th., Agostini,, B. \& Hasselbach, W. (1972) Naturwissenschaften 59, 521-522.

8. Frimmer, M., Kroker, R. \& Prostendörfer, J. (1974) NaunynSchmiedeberg Arch. Pharmakol. 284, 395-398.

9. Frimmer, M., Gries, J., Hegner, D. \& Schnorr, B. (1967) Naunyn-Schmiedeberg Arch. Pharmakol. 258, 197-214.

10. Goldberg, M., Fouad, F. M., Abd-El-Fattah, M. \& Ruhenstroth-Bauer, G. (1980) 15th Meeting of the European Association for the Study of the Liver, p. 83 .

11. Fouad, F. M., Abd-El-Fattah, M., Goldberg, M. \& Ruhenstroth-Bauer, G. (1980) 15th Meeting of the European Association for the Study of the Liver, p. 147.

12. Abd-El-Fattah, M. unpublished data. 